Катерина Павлишинець

Ужгородська спеціалізована школа I-III ступенів №5 з поглибленим вивченням іноземних мов ORCID ID 0000-0003-0973-9605

DOI 10.24139/2312-5993/2020.10/199-208

\title{
КОМПОНЕНТИ ТА КРИТЕРІЇ АДАПТАЦІЇ МАЙБУТНІХ УЧИТЕЛІВ ФІЗИЧНОЇ КУЛЬТУРИ ДО ПРОФЕСІЙНОЇ ДІЯЛЬНОСТІ У ПРОЦЕСІ ПЕДАГОГІЧНОЇ ПРАКТИКИ
}

у статті розглянуто теоретичні засади адаптації майбутніх учителів фрізичної культури до профресійної діяльності. Проаналізовано проблему ресрормування вищої освіти в контексті проблематики адаптації майбутніх учителів фрізичної культури до професійної діяльності у процесі педагогічної практики, як запоруки готовності майбутніх фахівців до такого виду діяльності та майбутньої успішної професійної діяльності. З'ясовано, що в сучасних умовах реалізації освітньої парадигми актуальним стає дослідження педагогічних умов та виявлення компонентів і критеріїв адаптації майбутніх учителів фізичної культури до профресійної діяльності у процесі педагогічної практики. Обгрунтовано й виявлено компоненти та критерії адаптації майбутніх учителів фрізичної культури до професійної діяльності у прочесі педагогічної практики.

Ключові слова: педагогічна освіта, фрізична культура, компоненти, критерії, адаптація до професійної діяльності, професійна підготовка майбутніх учителів фізкультури.

Постановка проблеми. Концептуальні засади реформування вищої освіти зумовлюють забезпечення підготовки конкурентоспроможних кваліфікованих кадрів, здатних до фахової діяльності та самореалізації, компетентнісного розвитку і безперервного самовдосконалення, упровадження наукових та цифрових технологій, творчих пошуків упродовж професійної діяльності, адаптації до нових умов праці у процесі педагогічної практики. Сучасному суспільству потрібний кваліфікований фахівець, який не тільки сформований як особистість, функціонально готовий як фахівець, але й готовий до професійної діяльності. У контексті зазначеного значна увага приділяється проблематиці адаптації майбутніх учителів фізичної культури до професійної діяльності у процесі педагогічної практики як запоруки готовності майбутніх фахівців до такого виду діяльності та майбутньої успішної професійної діяльності.

Аналіз актуальних досліджень. Теоретичні й методичні засади професійної підготовки майбутніх учителів фізичної культури в закладах вищої освіти розкриваються у філософських і психолого-педагогічних джерелах науковців - Н. Абашкіна, Г. Васянович, П. Воловик, О. Дубасенюк, 
І. Зязюн, Я. Камінецький, О. Коваленко, Т. Нейлор, Л. Пуховська, Л. Романишина, В. Сидоренко, М. Сметанський, Т. Сущенко, І. Хейстер, П. Яковишин, Т. Яценко та ін.; концептуальні засади підготовки майбутніх фахівців фізичної культури висвітлено в працях таких науковців О. Демінський, Т. Круцевич, Л. Сущенко, Б. Шиян, Ю. Шкребтій та ін.; питання підготовки до професійної діяльності та розвитку особистості - В. Бодрова, К Гуревича, Є. Єрмолаєвої, Б. Ломова та ін. концептуальні основи формування до професійної діяльності майбутніх учителів фізичної культури Л. Арефьєва, О. Атамась, Е. Вільчковський, О. Войтовська, Л. Гальченко, Л. Демінська, А. Ємець, Л. Коновальська, В. Корецький, Б. Максимчук, В. Наумчук, О. Омельчук, В. Омельяненко, Н. Самсутіна, Б. Шиян та ін.; формування готовності до професійної діяльності майбутніх учителів фізичної культури - Г. Акушев, Г. Драндров, Р. Карпюк, В. Наумчук, В. Філанковський та ін.

В умовах глобалізації та діджиталізації суспільства, удосконалення вищої освіти в Україні відповідно до Національної стратегії розвитку освіти в Україні на 2012-2021 рр, актуальною є проблема збереження та зміцнення здоров'я здобувачів освіти, що виділяє фізичну культуру й підвищує значущість підготовки майбутніх учителів фізичної культури до професійної діяльності. Це зумовлює необхідність удосконалення професійної підготовки майбутніх фахівців орієнтованих на пріоритетну підготовку у процесі педагогічної практики, здатних компетентнісно приймати рішення, кваліфіковано відповідати вимогам часу. В умовах реалізації компетентнісної парадигми освіти актуальним стає дослідження педагогічних умов та виявлення компонентів і критеріїв адаптації майбутніх учителів фізичної культури до професійної діяльності у процесі педагогічної практики.

Мета статті полягає у виявленні компонентів, критеріїв адаптації майбутніх учителів фізичної культури до професійної діяльності у процесі педагогічної практики.

Методи дослідження. Для досягнення мети дослідження й реалізації поставлених завдань було використано комплекс взаємопов'язаних методів дослідження: теоретичні - індукція, дедукція, аналіз, синтез, порівняння, узагальнення, систематизація психолого-педагогічної та навчальнометодичної літератури, навчальних планів і робочих програм - для визначення сучасного стану досліджуваної проблеми.

Виклад основного матеріалу. В умовах трансформації технічного прогресу, реформування галузі освіти, особлива увага зосереджується на інтелектуальному, моральному, особистісному, культурному та фаховому становленні майбутніх учителів їх адаптації до майбутньої професійної 
діяльності. Аналіз психолого-педагогічної літератури свідчить про актуальність такої проблематики та важливості її розв'язання відповідно до освітньої програми здобувачів освіти.

Підготовка майбутніх учителів фізичної культури до професійної діяльності передбачає комплексне вдосконалення змісту навчальних дисциплін, підходів, методів, використання інноваційних та цифрових технологій, шляхів організації освітнього процесу, безперервного моніторингу якості навчання, всебічного аналізу методологічних і психолого-педагогічних аспектів адаптації майбутніх учителів фізичної культури до професійної діяльності у процесі педагогічної практики. Із урахуванням процесу модернізації професійної підготовки майбутніх учителів фізичної культури осмисленню підлягає система формування педагогічної майстерності, професійного потенціалу із урахуванням специфіки та актуальних вимог до сучасних педагога, обґрунтування й визначення педагогічних умов адаптації майбутніх учителів фізичної культури до професійної діяльності у процесі педагогічної практики.

Процес адаптації майбутніх учителів фізичної культури до професійної діяльності у процесі педагогічної практики характеризується:

- наповненістю підготовленості до фахової діяльності (володіння системою фахових знань і вмінь, методикою фізкультурно-спортивних занять, технікою фізичних вправ, уміннями планувати і проводити основні види фізкультурних занять, знаннями раціонального застосування навчального та лабораторного обладнання, тренажерних пристроїв і спеціальної апаратури у процесі різних видів занять);

- напрацюванням умінь і навичок організації навчально-виховного процесу (уміння планувати та організовувати освітній процес, цілеспрямоване опанування досвідом упровадження вмінь і навичок в освітній процес у напрямі фізкультурно-оздоровчої і спортивно-масових робіт, проєктування індивідуальних освітніх траєкторій школярів із позицій здоров'язбереження);

- становленням професійно-значущих якостей (формування педагогічних здібностей, надбання позитивних вражень та бажань до фахової діяльності, формування ціннісних орієнтацій і первинного педагогічного досвіду, набуття фахових практичних навичок);

- набуттям ціннісного первинного досвіду діяльності, що забезпечить готовність до майбутньої трудової функції (набуття передового педагогічного та методичного досвіду, підвищення рівня власної 
професійної кваліфікації та педагогічної майстерності, надбання творчого впровадження активних методів та технології);

- спрямованістю на постійне самовдосконалення й підвищення загальнофахового рівня (цілеспрямоване надбання сукупності компетентностей, підвищення фахової майстерності організовувати власну педагогічну діяльність, надбання професійної спрямованості, підвищення рівня фахової культури та творчості).

Зважаючи на актуальність та необхідність вивчення даної проблеми, науково-методичні напрацювання педагогів-науковців щодо вдосконалення змісту, форм і методів підвищення якості підготовки майбутніх учителів фізичної культури до професійної діяльності, у межах дослідження особлива увага зосереджувалася на виявленні компонентів адаптації майбутніх учителів фізичної культури до професійної діяльності у процесі педагогічної практики. Оскільки цілеспрямований розвиток майбутнього педагога, фахова приналежність до соціального та науково-педагогічного досвіду, спрямованого на впровадження в навчально-виховну діяльність зі здобувачами освіти, характеризується адаптацією майбутніх учителів фізичної культури до професійної діяльності у процесі педагогічної практики. Тому перед закладами вищої освіти постає комплекс завдань, спрямованих на професійне зростання, цілеспрямований розвиток, особистісних властивостей майбутнього вчителя, становлення як фахівця та формування адаптації до професійної діяльності, оволодіння методологією та технологіями передового педагогічного наукового досвіду й фахової майстерності.

Особливої актуалізації потребує поглиблення вивчення психологопедагогічних і наукових основ адаптації майбутніх учителів фізичної культури до професійної діяльності у процесі педагогічної практики.

На думку Т. Колгуріна, практика ринкової економіки сприяє вирішенню завдань формування спеціалістів нового типу, ставлячи їх в умови природного соціального відбору, які потребують конкурентоспроможних фахівців, що прагнуть безперервного підвищення професійної майстерності та мають високу адаптаційну та професійну мобільність (Колгурина, 2002, с. 91).

Науковці Ю. Железняк, В. Кашкаров, І. Крацкевич також вважають, що сама успішність роботи вчителя фізичної культури залежить від рівня професіоналізму, який, на їх думку, визначається тим, які мотиви спонукають людину, який сенс має в його житті конкретна професійна діяльність, яку мету він ставить, а також які технології, засоби педагог використовує для досягнення цієї мети. Автори зауважують, що навчання в закладі вищої освіти 
забезпечує визначений рівень професійної готовності випускника, а чим вищий цей рівень, тим більше шансів, що становлення професіоналізму в майбутньому буде більш вдалим, тому що професіоналом людина стає тільки у процесі професійної діяльності (Колгурина, 2002, с. 93).

Аналіз психолого-педагогічних джерел свідчить про те, що на сьогодні проблематика адаптації майбутніх учителів фізичної культури до професійної діяльності у процесі педагогічної практики є недостатньо розробленою.

Так, досліджуючи професійну готовність майбутніх фахівців фізичної культури до професійної діяльності О. Притула виокремлює:

- мотиваційно-ціннісний (прийняття цілей і завдань щодо використання національних засобів фізичного виховання у професійній діяльності);

- когнітивно-технологічний (спрямованість на використання національних засобів фізичного виховання в навчально-виховному процесі);

- комунікативно-діяльнісний (самооцінка власних комунікативних і організаторських умінь);

- рефлексивно-творчий (здатність до саморозвитку, самоосвіти) компоненти (Притула, 2015, с. 255).

Дослідниця Л. Іванова, на основі наукових пошуків щодо оптимізації професійної підготовки фахівця в системі фізкультурно-педагогічної освіти, виокремлює сукупність компонентів:

- мотиваційного (мотиваційний компонент, на думку дослідниці, поєднує суб'єктні детермінанти діяльності: мотиви, установки, ціннісні орієнтації);

- інформаційного (інформаційний компонент відображає всі види і форми знань у зв'язку з професійною діяльністю: від відчуттів, сприйняття, уявлень до понять, учень, теорій);

- операційного (операційний компонент характеризується способами професійної діяльності, яка здійснюється на основі вмінь і навичок). Концепція компонентної структури професійної готовності, на думку автора, має на меті не ізольованість, локалізацію компонентів один від одного, а стійкі й закономірні відносини між ними (Іванова, 2007, с. 120).

Аналіз психолого-педагогічної літератури, наукові дослідження показали, що у структурі підготовки майбутніх учителів фізичної культури в закладах вищої освіти та адаптації до професійної діяльності у процесі педагогічної практики виявлено такі компоненти: мотиваційно-ціннісний, когнітивно-пізнавальний, практично-діяльнісний, особистіснорезультативний (рис. 1). 


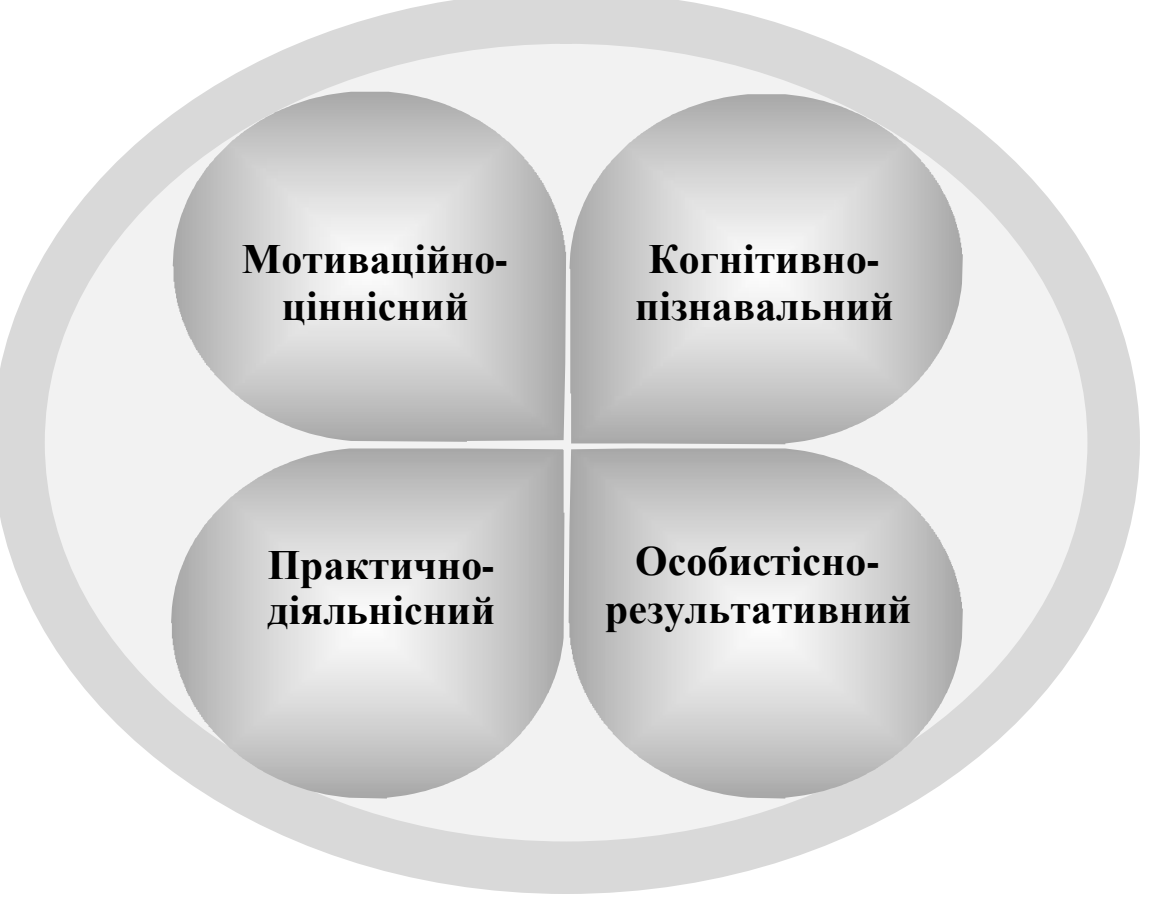

Рис. 1. Компоненти сформованості адаптації майбутніх учителів фізичної культури до професійної діяльності у процесі педагогічної практики

Зміст мотиваційно-ціннісного компонента передбачає формування системи цінностей, ідеалів, моральних норм, позитивного ставлення до педагогічної професії, стійких намірів фахової діяльності, інтересу до роботи педагога, професійних установок щодо адаптації до професійної діяльності, внутрішніх спонукань досягти успіху в педагогічній діяльності, бажань на успіх та свідомого прагнення бути вчителем фізичної культури, позитивного ставлення до самореалізації й саморозвитку, інтересів до здійснення безперервної самоосвіти.

Так, на думку $\epsilon$. Захаріної, формування мотивації майбутнього вчителя фізичної культури вимагає: по-перше, набуття знань, умінь, навичок для виконання своїх професійних завдань, по-друге, стимулювання з боку викладачів творчої організації навчальної роботи, заохочення до виконання самостійної роботи (Захаріна, 2012, с. 102).

Мотиваційно-ціннісний компонент $\epsilon$ визначальним у структурі формування адаптації майбутніх учителів фізичної культури до професійної діяльності у процесі педагогічної практики. Він виступає передумовою до самовдосконалення, професіоналізму та фахової майстерності. Критерієм обрано усвідомлення потреб, прагнень і цілей адаптації майбутніх учителів фізичної культури до професійної діяльності.

Когнітивно-пізнавальний компонент передбачає формування в майбутніх учителів фізичної культури фахових знань та вмінь, сукупності уявлень про майбутню педагогічну діяльність, умінь застосовувати фахові 
компетентності в педагогічній діяльності, здібностей до систематизації та узагальнення професійних умінь і навичок, здатності до самопізнання та вмінь керувати власними професійними знаннями та особистісною траєкторією їх здобуття, компетентнісних здібностей на саморозвиток через оволодіння педагогічним досвідом у процесі педагогічної практики.

До змісту когнітивно-пізнавального компоненту віднесено: пізнавальний потенціал протягом усієї педагогічної діяльності, уміння керувати особистісною траєкторією для самоосвіти та самовдосконалення, цілеспрямованість до творчого виконання професійних обов'язків із утіленням справжнього професіоналізму та майстерності. Критерієм обрано надбання адаптації майбутніх учителів фізичної культури до професійної діяльності у процесі педагогічної практики.

Практично-діяльнісний компонент передбачає набуття майбутніми вчителями фізичної культури практичних умінь і навичок самостійно організовувати та проводити фізкультурно-оздоровчі заняття й заходи, формування фахових практичних умінь і навичок за предметним спрямуванням, набуття й подальше застосування професійних базових i педагогічних компетентностей відповідно до цілей і змісту професійної діяльності майбутнього вчителя фізичної культури, оволодіння новими методами, прийомами та засобами в їх творчому поєднанні в професійній діяльності, формування компетентностей застосовувати на заняттях цифрові технології і контролювати якість освітнього процесу школярів, набуття майбутніми вчителями фізичної культури професійної підготовленості й умінь здійснювати самоаналіз власної педагогічної діяльності, оволодіння фаховими компетентностями для впровадження інноваційних методів та засобів у педагогічну діяльність, ефективне застосування накопиченого педагогічного досвіду в нових умовах, набуття навичок упровадження нестандартних підходів до вирішення освітніх завдань, формування фахових умінь надання професійної та консультативної допомоги, здобуття професійних навичок володіння фундаментальною та науково-практичною адаптацією до професійної діяльності. Критерієм обрано наявність адаптації майбутніх учителів фізичної культури до виконання різних видів професійної діяльності у процесі педагогічної практики.

Особистісно-результативний компонент включає особистісну траєкторію формування індивідуальної професійної траєкторії становлення майбутнього вчителя фізичної культури, професійної спрямованості, особистісних якостей набуття знань та вмінь, організаторських умінь, комунікативності, умінь аналізувати й організовувати професійне зростання, 
навичок імпровізації та модернізації відомого відповідно до нових завдань, умінь аналізувати та коректувати свою професійну діяльність, навичок контролювати й оцінювати власну поведінку, самооцінки своєї результативності та професійної підготовленості відповідно до вирішення професійних завдань, індивідуального стилю розумової діяльності майбутнього вчителя фізичної культури, здатності до самореалізації та творчого самовираження, постійного вдосконалення практичних навичок до професійної самореалізації, навчальної та методичної діяльності в різних ланках системи підвищення кваліфікації, навичок проводити наукові дослідження у професійній сфері, стратегії усебічного розвитку фізичних та професійних здібностей, значущих особистісних якостей для досягнення майстерності й вирішення фахових завдань. Критерієм обрано розвиненість провідних значущих якостей майбутніх учителів фізичної культури до здійснення професійної діяльності.

Потреби освітньої практики зумовлюють розроблення нових підходів до організації освіти щодо адаптації майбутніх учителів фізичної культури до професійної діяльності у процесі педагогічної практики, формування здатності самостійно проявляти компетентнісні вміння та навички в нестандартних умовах, виявлення вмінь на відтворення компетентнісних якостей особистості, удосконалення здатності майбутніх учителів до постійного самовдосконалення й саморозвитку.

Висновки та перспективи подальших наукових розвідок. Реформування національної системи освіти в Україні спонукають до вдосконалення професійної підготовки майбутніх учителів фізичного виховання, забезпечення їі конкурентоспроможності на європейському ринку праці, формування компетентних фахівців, готових до творчого пошуку, науково-практичної адаптації до професійної діяльності, фахового самовдосконалення та професіоналізму. У дослідженні виявлено й описано компоненти (мотиваційно-ціннісний, когнітивно-пізнавальний, практичнодіяльнісний, особистісно-результативний) та критерії (усвідомлення потреб, прагнень і цілей адаптації майбутніх учителів фізичної культури до професійної діяльності; надбання адаптації майбутніх учителів фізичної культури до професійної діяльності у процесі педагогічної практики; наявність адаптації майбутніх учителів фізичної культури до виконання різних видів професійної діяльності у процесі педагогічної практики; розвиненість провідних значущих якостей майбутніх учителів фізичної культури до здійснення професійної діяльності) адаптації майбутніх учителів фізичної культури до професійної діяльності у процесі педагогічної практики. 
Зважаючи на той факт, що дана стаття не вичерпує всіх аспектів досліджуваної проблеми, перспективи подальших наукових розвідок убачаємо у визначенні стану сформованості адаптації майбутніх учителів фізичної культури до професійної діяльності у процесі педагогічної практики.

\section{ЛІТЕРАТУРА}

Захаріна, Є. А. (2012). Професійна підготовка майбутніх учителів фрізичної культури до позакласної та позашкільної оздоровчо-виховної роботи: теорія та методика. Запоріжжя (Zakharina, Ye. A. (2012). Professional training of future teachers of physical culture for extracurricular and out-of-school health-improving work. Zaporizhzhia).

Іванова, Л.І. (2007). Підготовка майбутніх учителів фізичної культури до фізкультурно-оздоровчої роботи з учнями загальноосвітніх навчальних закладів (дис. ... канд. пед. наук: 13.00.04). Київ (Ivanova, L. I. (2007). Preparation of future physical education teachers for physical culture and health work with students of secondary schools (PhD thesis). Kyiv).

Колгурина, Т.В. (2002). Формирование конкурентоспособности студентоввыпускников вузов физической культуры (дис. ... канд. пед. наук: 13.00.04). Санкт-Петербург (Colgurina, T. V. (2002). Formation of competitiveness of graduate students of physical culture universities (PhD thesis). Saint Petersburg).

Притула, О.Л. (2015). Виховання майбутніх фахівців фізичної культури в традиціях запорізького козацтва. Педагогіка формування творчої особистості у вищій $i$ загальноосвітній школах, (сс. 252-257). Запоріжжя (Prytula, O. L. (2015). Education of future physical culture specialists in the tradition of the conspiracy cossack. Pedagogy of the formation of a good education at schools and out-of-town schools, (pp. 252-257). Zaporizhzhia).

\section{PEЗЮME}

Павлишинец Екатерина. Компоненты и критерии адаптации будущих учителей физической культуры к профессиональной деятельности в процессе педагогической практики.

В статье рассмотрены теоретические основы адаптации будущих учителей физической культуры к профрессиональной деятельности. Проанализирована проблема реформирования высшего образования в контексте проблематики адаптации будущих учителей физической культуры к профессиональной деятельности в прочессе педагогической практики как залога готовности будущих специалистов к такому виду деятельности и будущей успешной профессиональной деятельности. Установлено, что в современных условиях реализации компетентностной парадигмы образования актуальным становится исследование педагогических условий и выявления компонентов и критериев адаптации будущих учителей физической культуры к профессиональной деятельности в процессе педагогической практики. Обосновано и обнаружены компоненты и критерии адаптации будущих учителей физической культуры $к$ профессиональной деятельности в прочессе педагогчческой практики.

Ключевые слова: педагогическое образование, фризическая культура, компоненты, критерии, адаптация к профессиональной деятельности, профессиональная подготовка будущих учителей физкультуры. 


\section{SUMMARY}

PaMlyshynets Kateryna Components and criteria of adaptation of future physical education teachers to professional activity in the process of pedagogical practice.

The article considers the theoretical foundations of adaptation of future physical education teachers to professional activity. The problem of reforming higher education in the context of the problems of adaptation of future physical education teachers to professional activity in the process of pedagogical practice is analyzed, as a guarantee of readiness of future specialists for this type of activity and future successful professional activity. It is found out that in modern conditions of realization of the competence paradigm of education research of pedagogical conditions and revealing of components and criteria of adaptation of future teachers of physical culture to professional activity in the course of pedagogical practice becomes actual. The components and criteria of adaptation of future physical education teachers to professional activity in the process of pedagogical practice are substantiated and revealed. It was found that the content of the motivational-value component involves formation of a system of desires for success and a conscious desire to be a teacher of physical culture, a positive attitude to self-realization and self-development, interests in continuous self-education. The criterion is the awareness of the needs, aspirations and goals of adaptation of future physical education teachers to professional activity. The content of the cognitive component includes cognitive potential throughout the pedagogical activity, the ability to manage a personal trajectory for self-education and selfimprovement, focus on creative performance of professional duties with the embodiment of true professionalism and proficiency. The criterion is acquisition of the future physical education teachers to professional activity in the process of pedagogical practice. It was found that the practical-activity component involves formation of professional practical skills and abilities in the subject area, mastering new methods and techniques and tools in their creative combination in professional activities. The criterion is presence of adaptation of future physical education teachers to perform various types of professional activities in the process of pedagogical practice. It is revealed that the personal-effective component includes the improvement of practical skills for professional self-realization, educational and methodological activities in various parts of the system of advanced training, skills to conduct research in the professional sphere. The criterion is development of the leading significant qualities of future physical education teachers to carry out professional activities.

Key words pedagogical education, physical culture, components, criteria, adaptation to professional activity, professional training of future physical education teachers.

\section{удк 378.015.31-044.337(045)}

Олена Павлова

Комунальний заклад «Харківська гуманітарнопедагогічна академія» Харківської обласної ради

ORCID ID 0000-0002-4014-7440

DOI 10.24139/2312-5993/2020.10/208-218

\section{ФОРМУВАННЯ ПОТРЕБИ ПРОФЕСІЙНО-ПЕДАГОГІЧНОГО САМОВДОСКОНАЛЕННЯ МАЙБУТНІХ УЧИТЕЛІВ}

Викладено дані теоретичного аналізу проблеми професійно-педагогічного самовдосконалення майбутніх учителів, необхідність формування якого обумовлена інтенсивною модернізацією системи освіти. Проведено аналіз наукових джерел із означеної проблеми. Представлено розуміння потреби професійно-педагогічного 